\title{
Enhanced Ocean Observational Capability
}

A. M. Volpe, B. K. Esser

January 10, 2000

U.S. Department of Energy

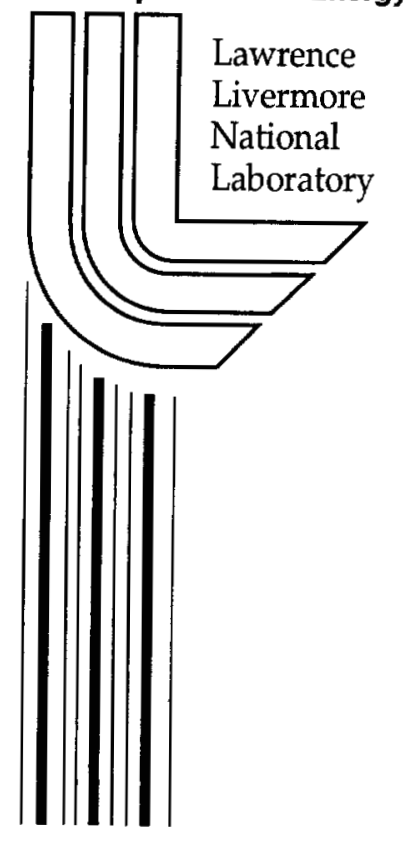




\section{DISCLAIMER}

This document was prepared as an account of work sponsored by an agency of the United States Government. Neither the United States Government nor the University of California nor any of their employees, makes any warranty, express or implied, or assumes any legal liability or responsibility for the accuracy, completeness, or usefulness of any information, apparatus, product, or process disclosed, or represents that its use would not infringe privately owned rights. Reference herein to any specific commercial product, process, or service by trade name, trademark, manufacturer, or otherwise, does not necessarily constitute or imply its endorsement, recommendation, or favoring by the United States Government or the University of California. The views and opinions of authors expressed herein do not necessarily state or reflect those of the United States Government or the University of California, and shall not be used for advertising or product endorsement purposes.

This work was performed under the auspices of the U. S. Department of Energy by the University of California, Lawrence Livermore National Laboratory under Contract No. W-7405-Eng-48.

This report has been reproduced directly from the best available copy.

Available electronically at http://www.doc.gov/bridge

Available for a processing fee to U.S. Department of Energy

And its contractors in paper from

U.S. Department of Energy

Office of Scientific and Technical Information

P.O. Box 62

Oak Ridge, TN 37831-0062

Telephone: (865) 576-8401

Facsimile: (865) 576-5728

E-mail: reports@adonis.osti.gov

Available for the sale to the public from

U.S. Department of Commerce

National Technical Information Service

5285 Port Royal Road

Springfield, VA 22161

Telephone: (800) 553-6847

Facsimile: (703) 605-6900

E-mail: orders@ntis.fedworld.gov

Online ordering: http://www.ntis.gov/ordering.htm

\section{OR}

Lawrence Livermore National Laboratory

Technical Information Department's Digital Library

http://www.llnl.gov/tid/Library.html 


\section{ABSTRACT}

Coastal oceans are vital to world health and sustenance. Technology that enables new observations has always been the driver of discovery in ocean sciences. In this context, we describe the first at sea deployment and operation of an inductively coupled plasma mass spectrometer (ICPMS) for continuous measurement of trace elements in seawater. The purpose of these experiments was to demonstrate that an ICPMS could be operated in a corrosive and high vibration environment with no degradation in performance. Significant advances occurred this past year due to ship time provided by Scripps Institution of Oceanography (UCSD), as well as that funded through this project. Evaluation at sea involved performance testing and characterization of several real-time seawater analysis modes. We show that mass spectrometers can rapidly, precisely and accurately determine ultratrace metal concentrations in seawater, thus allowing high-resolution mapping of large areas of surface seawater. This analytical capability represents a significant advance toward real-time observation and understanding of water mass chemistry in dynamic coastal environments. In addition, a joint LLNL-SIO workshop was convened to define and design new technologies for ocean observation. Finally, collaborative efforts were initiated with atmospheric scientists at LLNL to identify realistic coastal ocean and river simulation models to support real-time analysis and modeling of hazardous material releases in coastal waterways.

\section{INTRODUCTION}

Oceans and coastal ecosystems have played a critical role in regulating planetary biology and chemistry throughout Earth's history. Further, they are vital to the well-being of people all over the world. Mankind is exerting tremendous pressure on coastal oceans through over-fishing, land runoff, waste disposal, spills and destruction of habitats. However, ocean scientific research is still very exploratory, and until recently, vast regions of the oceans were inaccessible to scientific observation. Observational capability has always been the driver of new discovery in ocean sciences.

Active scientific research in ocean sciences is concerned with understanding the interplay among physical, biologic, geologic, and chemical processes that control the 
complex exchanges between the atmosphere, biosphere, land, ocean and seafloor (see for review: Butler, 1998; Falkowski et al., 1998; Jickells, 1998; McGowan et al., 1998; Uppenbrink et al., 1998). Knowledge gleaned from this basic ocean research is increasingly applied to problems in coastal oceans that will concern society for many years. At the direction of the National Academy of Sciences, the Ocean Studies Board (NRC, 1998), identified several areas that offered great opportunity for scientific advancement and improvement of life on the planet, if the research efforts were intensified. These areas involve:

- improving the health and productivity of coastal oceans

- sustaining ocean ecosystems

- predicting climate change over human lifetime scales

The Ocean Studies Board recognized that meeting these broad challenges requires a commitment to provide new technologies and improved observational capabilities (NRC, 1998). Until recently, geochemical measurements of ocean waters were made on discrete bottle samples. Although important for allowing a first-order characterization, such a sampling strategy provides a record that is discontinuous in time and space. In dynamic coastal environments, this record is inadequate for understanding the provenance of water masses, and for quantifying the fluxes and impact of anthropogenic inputs on the coastal biosphere.

In this regard, we developed a continuous chemical measurement capability based on commercially available ICPMS instrumentation. The ICPMS is a proven technology using radio frequency power to generate ionization plasma and drive quadrupole filters for mass discrimination. Scientists at LLNL have been involved with numerous development stages, since inception of this technology nearly two decades ago. It is appropriate technology to adapt for ocean chemistry, because it achieves low detection levels at the parts-per-trillion level with high precision and accuracy ( $1 \%$ or better). The technologic challenges we met include operation of a mass spectrometer under extremely harsh vibration and corrosion conditions to deliver high sensitivity measurements at a rapid rate necessary to acquire large spatially and temporally continuous data sets. 


\section{EXPERIMENTAL METHODS}

Components of the at-sea ICPMS capability have been evaluated in various locales including San Francisco Bay and adjoining coastal waters. A preliminary report described sample collection of San Francisco Bay waters, and ICPMS method development procedures (Esser and Volpe, 1998). The quadrupole ICPMS was a Hewlett Packard HP4500 laboratory benchtop instrument that was modified for shipboard operation. Components include $27.12 \mathrm{MHz}$ crystal-controlled ICP source, turbo-pumped three-stage vacuum system, Omega lens ion optics, hyperbolic cross section molybdenum quadrupole mass analyzer with $3.0 \mathrm{MHz}$ RF generator, and computer control operation and data acquisition. The chassis is $0.6 \mathrm{~m} \mathrm{H} \times 1.1 \mathrm{~m} \mathrm{~W} \times$ $0.6 \mathrm{~m} \mathrm{D}$ and weighs approximately $135 \mathrm{~kg}$. Two rough pumps (Edwards) and a water chiller (Neslab) were mounted on the floor underneath the ICPMS chassis.

\section{On-line Dilution}

In order to analyze seawater at rapid analytical rates, an on-line dilution and internal standardization system was fabricated. This system mixes seawater with a diluent containing internal standard elements, and delivers the analyte solution directly to the ICPMS plasma source interface. The optimal dilution factor was determined by the trade-off between loss of signal due to dilution effects and the loss of signal due to matrix effects. Measured mixing ratios were consistently 22 parts diluent to 1 part seawater. Dilution and mixing of discrete samples, such as the calibration standards, were identical to the in-line seawater method.

Each acquisition took 36 seconds/repetition (including settle times between masses). Data reduction and processing sequence information using the manufacturer's software took an additional 20 seconds, for a total analytical cycle of less than 1 minute for 1 repetition/sample, or about 6 minutes for 10 repetition/sample. Software improvements (Tom Kay, Hewlett Packard Chemical Analysis Group, personal communication), and judicious elimination of unnecessary masses will bring down total analytical cycle to less than 30 seconds for 1 repetition/sample with no loss in analytical precision. For each element, concentration was determined by external calibration against the appropriate set of calibration standards using a simple linear calibration 
curve after internal standardization against the nearest internal standard mass. For example, ${ }^{27} \mathrm{Al}$ and ${ }^{55} \mathrm{Mn}$ were standardized using ${ }^{45} \mathrm{Sc}$. The only explicit correction made for polyatomic interference was on the ${ }^{65} \mathrm{Cu}$ mass.

\section{On-line Preconcentration}

Flow-injection systems utilizing low-pressure ion chromatography with 8hydroxyquinoline or iminodiacetic acid resins have been coupled to lab-based ICPMS in research environments, and are capable of sub-ng/mL detection limits with turnaround times of a few minutes (Bloxham et al., 1994; DeCarlo and Resing, 1998; Ebdon et al., 1993; Willie et al., 1998). Hewlett-Packard has just introduced an on-line system customized for the HP4500 ICPMS. The HP Integrated Sample Introduction System (ISIS) consists of 1) two high-precision, low-pulsation, three-channel peristaltic pumps, 2) two trace metal-free 6-port switching valves, 3) the capability to control additional devices such as external switching valves, and 4) complete integration with the Windows NT version of the HP4500 control software.

Hewlett Packard provided an ISIS system for evaluation during the September experiments in San Diego coastal waters. The system is extremely flexible, allowing online auto-dilution, high-speed sample analysis, hydride generation, matrix elimination and pre-concentration, and low-pressure chromatography with a variety of microcolumns. The ISIS system will allow full automation and complete integration of these capabilities, and expand the range of metals, which we can determine at sea. As an example, hydride generation will allow us to map toxic metals such as arsenic, selenium, and mercury.

Toyopearl® AF-Chelate $650 \mathrm{M}$ resin, an iminodiacetic acid resin with a macroporous methacryalate backbone, was used as the ion-exchanger. This resin is commerically available, and has been employed to process seawater for preconcentration and matrix elimination in FIA-ICPMS (Willie et al., 1998). At LLNL, we constructed a column of $1 / 8^{\prime \prime}$ OD, 1/16" ID Tefzel ${ }^{\circledR}$ tubing and 1/8" natural PEEK fittings. The resultant $3-\mathrm{cm}$ column contains approximately $50 \mu \mathrm{L}$ of resin, does not leak and will sustain flow rates in excess of $2 \mathrm{~mL} /$ minute at peristaltic pump pressures, and can be easily incorporated into or removed from the FIA system with standard 1/8" chromatography fittings. In addition to the analytic column, clean-up columns 
constructed in the same manner, were placed on the buffer line and carrier line to reduce reagent blanks.

An automated flow injection scheme was designed and tested using reference seawater standards from the National Research Council of Canada. Each analysis takes four minutes and processes $3 \mathrm{~mL}$ of seawater. The protocol efficiently separates transistion metals from seawater matrix ions; measured seawater isotopic ratios for metals of interest are identical to ratios in aqueous standard ratios. In additon, the technique is sufficently accurate, precise and sensitive for surveying coastal seawater.

Isotope Ratios in Seawater and Aqueous Standard

\begin{tabular}{ccccc}
\hline $\begin{array}{c}\text { Isotope } \\
\text { Ratio }\end{array}$ & Interference & $\begin{array}{c}\text { Nominal } \\
\text { Value }\end{array}$ & $\begin{array}{c}\text { Aqueous Std } \\
(\mathrm{n}=5)\end{array}$ & $\begin{array}{c}\text { CASS-3 } \\
(\mathrm{n}=8)\end{array}$ \\
\hline${ }^{60} \mathrm{Ni} /{ }^{88} \mathrm{Ni}$ & ${ }^{23} \mathrm{Na}^{35} \mathrm{Cl}^{+}$ & 2.62 & $2.43 \pm 0.02$ & $2.41 \pm 0.03$ \\
${ }^{63} \mathrm{Cu} /{ }^{65} \mathrm{Cu}$ & ${ }^{23} \mathrm{Na}^{40} \mathrm{Ar}^{+}$ & 2.24 & $2.07 \pm 0.02$ & $2.16 \pm 0.01$ \\
${ }^{64} \mathrm{Zn} /{ }^{66} \mathrm{Zn}$ & ${ }^{24} \mathrm{Mg}^{40} \mathrm{Ar}^{+}$ & 1.74 & $1.78 \pm 0.02$ & $1.80 \pm 0.02$ \\
\hline
\end{tabular}

Mean \pm 1 sd, uncorrected for instrumental mass bias.

Limits of Detection and Reference Standard Results

\begin{tabular}{cccc}
\hline Element & $\begin{array}{c}\text { LOD } \\
(\mathrm{ng} / \mathrm{mL})\end{array}$ & $\begin{array}{c}\text { CASS-3 } \\
\text { measured }\end{array}$ & $\begin{array}{c}\text { CASS-3 } \\
\text { certified }\end{array}$ \\
\hline $\mathrm{Mn}$ & 0.030 & $2.52 \pm 0.12$ & $2.51 \pm 0.36$ \\
$\mathrm{Ni}$ & 0.004 & $0.334 \pm 0.009$ & $0.386 \pm 0.062$ \\
$\mathrm{Cu}$ & 0.004 & $0.502 \pm 0.016$ & $0.517 \pm 0.062$ \\
$\mathrm{Zn}$ & 0.002 & $1.25 \pm 0.04$ & $1.24 \pm 0.25$ \\
$\mathrm{Cd}$ & 0.002 & $0.034 \pm 0.001$ & $0.030 \pm 0.005$ \\
$\mathrm{~Pb}$ & 0.002 & $0.009 \pm 0.001$ & $0.012 \pm 0.004$ \\
\hline
\end{tabular}

Mean \pm 1 sd ( $n=5$ ) for CASS-3 measured;

mean $\pm 95 \%$ confidence interval for CASS-3 certified. 


\section{RESULTS}

\section{Alarcon Expedition}

At the invitation of SIO faculty and Director, LLNL scientists participated in extended at-sea tests of the ICPMS equipment during October 17 to November 4, 1998 aboard the SIO research vessel Roger Revelle during the Alarcon expedition. Though the primary objective was to study aspects of the ocean ridge in the Gulf of California, the expedition provided an extremely cost effective opportunity for LLNL to conduct atsea evaluation of instrumentation and operational capability. Measurement and testing of the ICP mass spectrometer and ancillary equipment was performed in a specially outfitted iso-van secured on the aft-deck of the Revelle. To our knowledge, this experiment was the first at-sea test of an Inductively Coupled Plasma Mass Spectrometer (ICPMS). The purpose was to evaluate ICPMS operational capability to provide continuous chemical data of surface waters under open ocean conditions.

Figures 1-4 graphically represent analytical capability. The figures show continuous data collected during the 3-4 day return transect from warm waters at the mouth of the Gulf of California $\left(23^{\circ} \mathrm{N}\right)$ through Baja California coastal waters to San Diego $\left(32.5^{\circ} \mathrm{N}\right)$. About six hours were spent transiting from the Alarcon Basin to Cabo San Lucas, followed by a 70-hour southeast-to-northwest transit to San Diego (Figure 1). On Figure 2, panel 1 shows continuous salinity and temperature data; panel 2 shows continuous dissolved organic matter (DOM), chlorophyll and turbidity data. Both of these data sets were averaged over 30 -second time intervals. Panel 3 shows nutrient data from water samples taken hourly and returned for post-cruise analysis. Panel 4 shows continuous ICPMS data for $\mathrm{Ba}$, Mo, and Mn. Metal data were collected once a minute and averaged over 5 minute intervals.

Major transitions in water properties along the Baja transect occur at Cabo San Lucas $\left(22.8^{\circ} \mathrm{N}\right)$, Cabo San Lazaro $\left(24.8^{\circ} \mathrm{N}\right)$, Punta Eugenia $\left(24.8^{\circ} \mathrm{N}\right)$, and near the U.S.-Mexico border $\left(32.5^{\circ} \mathrm{N}\right)$. Surface circulation in the coastal region between Cabo San Lucas and San Diego is dominated by the California Current and California Countercurrent. These waters form by mixing of Pacific Subarctic, North Pacific Central, Equatorial Pacific, and upwelled coastal water (Lynn and Simpson, 1987). In the Alarcon Basin, surface water is extremely warm and salty, which is typical of evaporated Equatorial Pacific water (Bray, 1988). North of Cabo San Lazaro, the ship 
crossed into the California Current, and surface water temperature and salinity drop dramatically. Another small but significant drop in temperature and salinity occurs north of Punta Eugenia, and may correspond to the boundary between the California Current and the California Countercurrent. Near Punta Eugenia, the ship surveyed near the coast (Figures 1-3). Sharp and correlated changes in temperature, salinity, DOM, chlorophyll, turbidity and nutrients are indicative of nearshore upwelling and associated biological productivity. The waters in this area are productive fishing grounds. As the track passes Tijuana and enters San Diego Bay, nutrients, chlorophyll, and DOM all increase significantly (Segovia-Zavala et al., 1998). This rise is related to a sharp onshore component of the California Current system dividing northern eutrophic waters from southern oligotropic waters (Segovia-Zavala et al., 1998).

The trace metal profiles are used to constrain oceanographic processes such as mixing, upwelling, and biological productivity (figs. 2-4). Molybdenum is conservative (i.e. covaries with salinity) and serves as a check on ICPMS data quality. The average measured Mo value for this field test was $10.1 \pm 0.5 \mathrm{ng} / \mathrm{mL}$, which compares well to the accepted seawater value of $10 \mathrm{ng} / \mathrm{mL}$ for $35 \%$ salinity water (Nozaki, 1997). Manganese is important in toxic metal cycling and is a tracer of riverine, atmospheric and shallow-sediment input to coastal waters. During the Baja transect, dissolved $\mathrm{Mn}$ was only detected in the Alarcon Basin and in coastal water near the Mexico/US border. These findings are consistent with low Mn concentrations in North Pacific coastal waters (< $0.5 \mathrm{ng} / \mathrm{mL}$ ) (Klinkhammer and Bender, 1980; Landing and Bruland, 1980), with Mn inputs from hydrothermal activity and sediments (Gulf of California), and with $\mathrm{Mn}$ input from land run-off. In recent years, barium has been used to investigate changes in ocean circulation, upwelling conditions, and surface water productivity over a variety of time scales, and to measure net export of carbon from the euphotic zone (Falkner et al., 1993). In the coastal upwelling region near Punta Eugenia, dissolved $\mathrm{Ba}$ experiences strong surface water depletions, which correlate with nutrient patterns and productivity indices.

Before the final transect, the ICPMS operated daily (12 days) and met all performance criteria for land-based mass spectrometry operation. During the final transect the instrument ran for 66 hours with no degradation in performance. The spatial resolution of the trace metal data was about 300 meters across nearly 1500 
kilometers of coastal water. This synoptic capability provides a major advance in our ability to observe phenomena affecting coastal marine biology and chemistry that directly addresses the challenges set forth by the National Academy of Sciences (NRC, 1998).

\section{San Diego Bay and Coastal Waters}

At-sea science experiments in the Southern California Bight were conducted 1317 September aboard the RN Robert G. Sproul. With SIO collaborators, we pursued the scientific application of an enhanced ocean observational capability as a first step towards full characterization of the impact of harbor, bay and lagoon outflow on coastal waters along the Southern California Bight. Though it is clear that high population density along the Southern California coastline has a significant effect on water quality off the coast, the details of transfer from land to ocean in this area are poorly understood. In particular, the fate and dispersal of plumes from Tijuana River, San Diego Harbor and Mission Bay have been little studied. These plumes are the primary mechanism for exchange and transfer of nutrients, biologic organisms (larvae) and trace metals between the bays and the coastal ocean.

Details of the rates of exchange of nutrients and trace metals in mixed waters is not well known; the effects of these trace metals (micro-nutrients) on biologic productivity, and tidal flushing on nutrient supply to surface waters are unclear. Also, the short term fate of dissolved and particulate material as it flushes from the bays is not known. A first step in understanding these aspects of coastal biogeochemical processes is to quantify the distribution, both temporal and spatial, of important biologic, chemical and isotopic species. The transport and dispersal of planktonic larvae play critical roles in the population dynamics of many coastal marine species (e.g., Roughgarden et al. 1988). However, studies of larval transport have suffered from an inability to know the origins of sampled larvae (Levin, 1990). Levin and co-workers have recently developed an elemental-based method to determine larval origins and quantify bay-ocean exchange of planktonic invertebrate larvae (DiBacco and Levin, in prep). Both naturally-occurring elements and pollutants act as tags which distinguish larvae spawned in San Diego Bay from those in coastal settings or neighboring bays. Use of 
this approach relies on accurate, synoptic studies of trace element distributions in bay and coastal waters.

The main purpose of this survey was to use the at-sea ICPMS to quantify elemental composition of waters in Southern California embayments and the coastal zone in conjunction with simultaneous sampling of invertebrate larvae (crabs, barnacles, bivalves). Water chemistry measurements will permit characterization of the spatial variation (within bay, bay vs coastal) and temporal shifts (within the tidal cycle) in elemental signatures of water and relate these to 'elemental fingerprints' of larvae. Combined with larval concentration data, this information will be used to quantify larval fluxes between San Diego Bay and coastal waters. Bay-ocean exchange has significant implications for larval development and survivorship (DiBacco, submitted), as well as for gene flow and population maintenance (Gaines and Bertness, 1992).

Satellite imagery of the oceans currently focuses on parameters such as ocean color, which is largely a reflection of biological activity. With the launch and operation of a new generation of multi-spectral imaging systems (e.g., SeaWIFs), the in-situ, real time ocean chemistry capability will provide important ground-truth information about sediment load, chemical parameters and biologic productivity for selected imaged areas. In addition to nutrients, some trace chemical constituents have an important influence on biological productivity. Transport, interaction and fate of riverine suspended and dissolved material into coastal and open ocean areas is an area of active research amenable to remote sensing and imagery. The experiments in September will permit integration of the chemical and satellite image data, which has great potential for synoptic spatial information.

In support of the San Diego coastal surveys, Dr. Mitchell and researchers in biooptics at SIO provided in-situ analyses of chlorophyll and light absorption properties of seawater (Kahru \& Mitchell, 1998; Mitchell \& Kahru, 1998; Sosik \& Mitchell, 1995). They analyzed SeaWiFS ocean color (chlorophyll) and AVHRR sea surface temperature SST data for periods coincident with collection of high-resolution chemical and oceanographic data, and analyzed both global area coverage (GAC) and local area coverage (LAC) spatial resolution. They supported at sea experiments providing the cruise with the LAC satellite data. 
Trace metal and sensor data from the San Diego coastal surveys are shown in Figures 5 and 6 . The experiment was a stunning success. The data show that San Diego Bay is clearly enriched in $\mathrm{Mn}, \mathrm{Ni}, \mathrm{Cu}$ and $\mathrm{Zn}$ with respect to the coastal ocean (Figure 5). The enrichment patterns can be used to tag Bay water as it enters the the adjacent coastal ocean. Figure 6 shows a detail view of a coastal plume of water near the mouth of San Diego Bay which is more saline and colder than surrounding waters. Since San Diego Bay surface water is more saline and warmer than coastal surface water, the source of the plume water is ambiguous. The plume, however, is also enriched in all four trace metals with ratios characteristic of a Bay source. The resolution in mapping trace metals with this survey technique is less than $1 \mathrm{~km}$ and will allow detailed mapping of plumes and a better understanding of the transport of pollutants in the coastal ocean. The spatial gradients revealed by detailed mapping (Figure 5) also give insight into the mechanisms by which metals remain enriched in Bay waters. All metals show strongly increasing monotonic gradients from the mouth to the head of the Bay. Such a pattern argues against a strong point sources, and is consistent with nonpoint source pollution sources (e.g. sediment-water interactions; urban and industrial runoff; and ship activities) and metal residences times being controlled by water exchange between the Bay and coastal ocean.

\section{CONCLUSIONS}

We met all FY99 LDRD milestones. To date, we have demonstrated that the ICPMS can be successfully taken to the field without deleterious effect, and used to rapidly determine seawater metal concentrations in the upper portion of the trace metal range $(1-10 \mathrm{ng} / \mathrm{mL})$ by simply diluting seawater with an external standard. This capability allows us to map important biologically active metals such as $\mathrm{Mn}$ and $\mathrm{Ba}$ at high spatial resolution. Extending this capability to a wider range of metals, including metals present at lower concentrations (such as $\mathrm{Pb}$ and $\mathrm{Cd}$ ) and metals that suffer from seawater matrix interference (such as $\mathrm{Zn}, \mathrm{Cu}$ and $\mathrm{Ni}$ ), required on-line preconcentration and matrix elimination. The combination of field-based instrumentation, $\mathrm{pg} / \mathrm{mL}$ detection limits, and rapid analytical cycling allowed mapping of nutrient and 
toxic trace metals in the estuarine and coastal environment at spatial resolutions currently unachievable. The results will dramatically increase our understanding of the distribution and geochemistry of these metals, and of near-shore ocean biology and chemistry. 


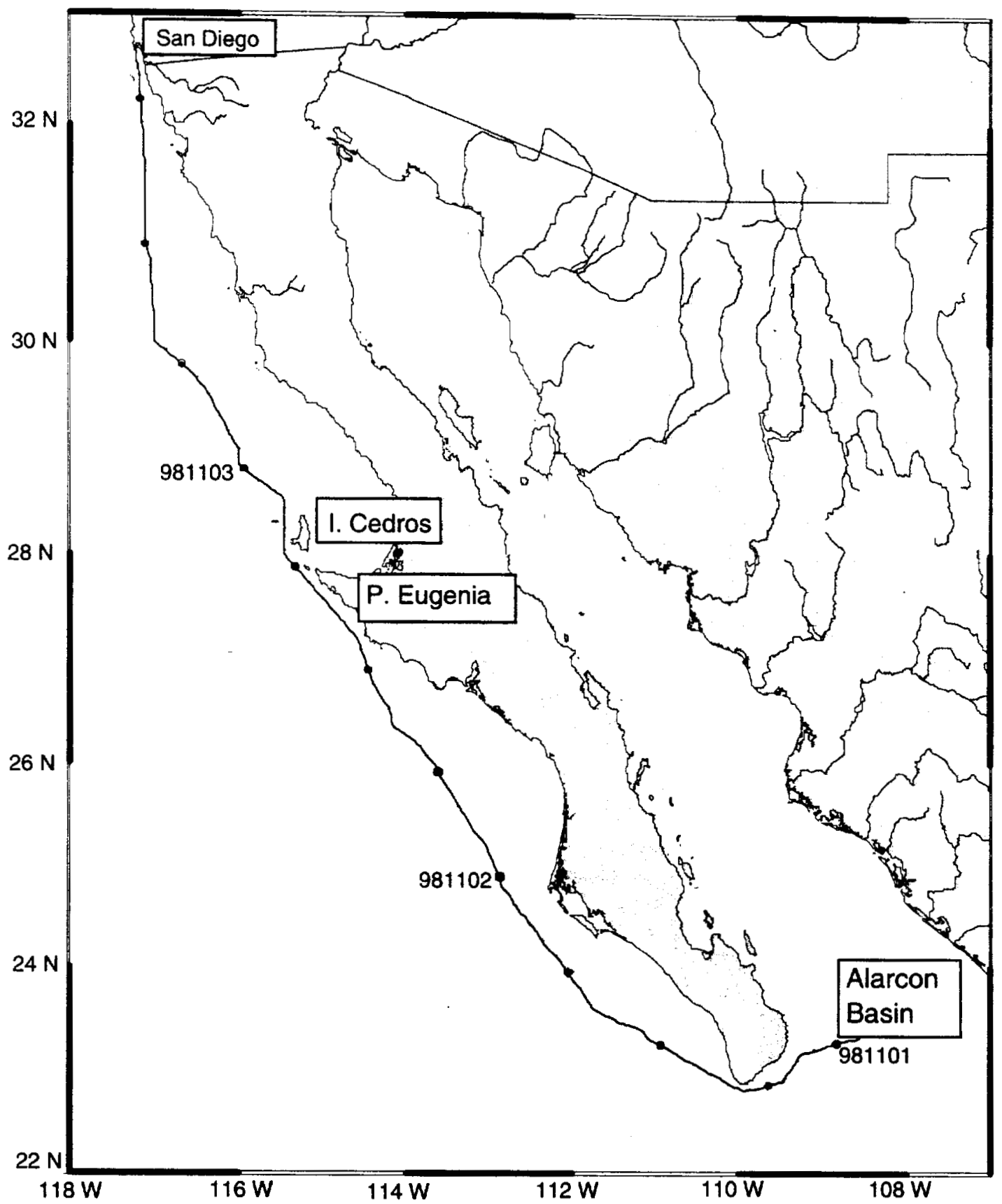

Figure 1. Ship track showing location of RN Revelle on the transit from the Alarcon basin to San Diego offshore Baja Mexico. Dates are yymmdd at 00:00 GMT with tick marks showing ship location at six hour intervals. 

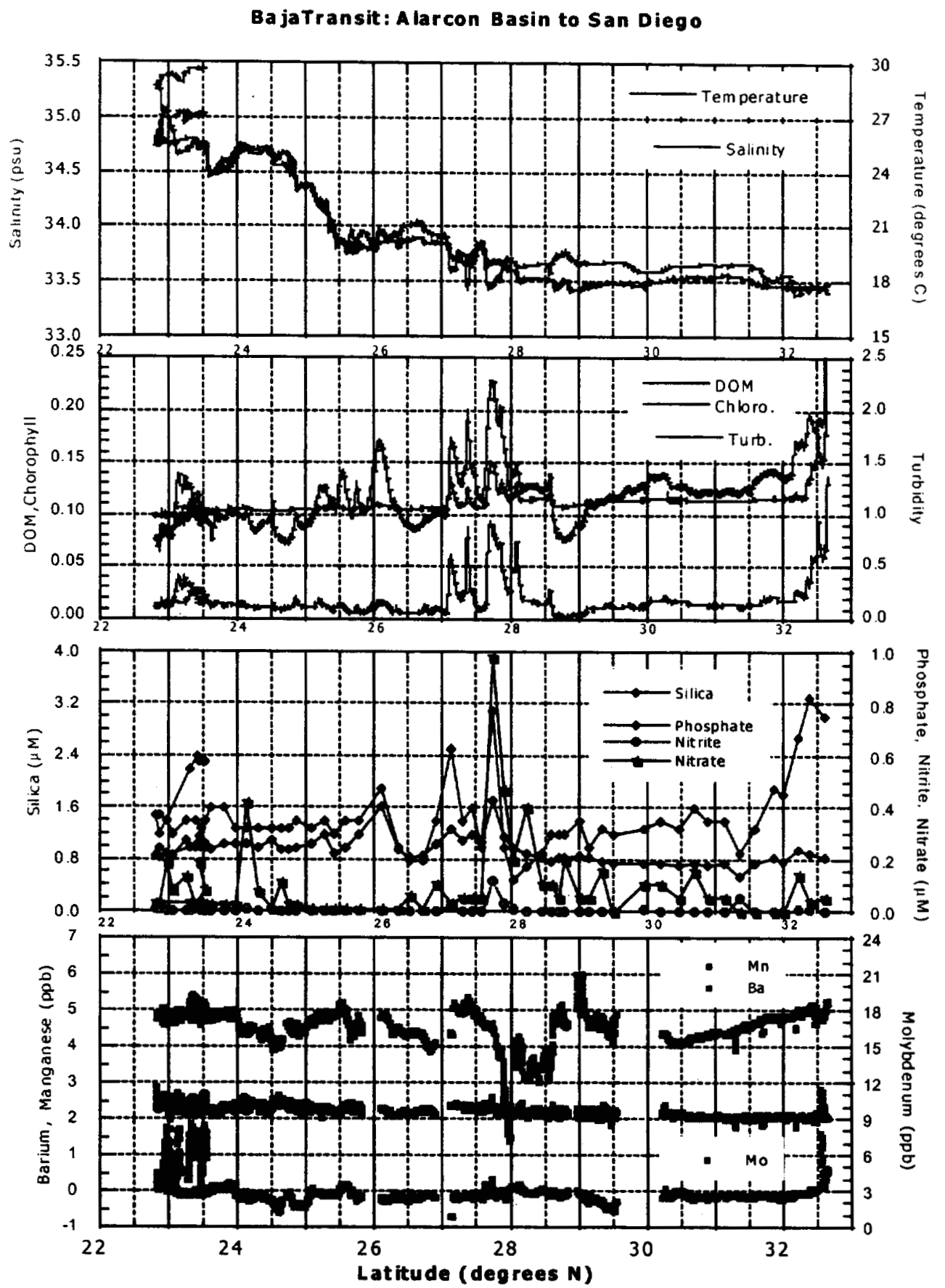

Figure 2. Oceanographic and trace element data taken aboard the RN Revelle (UC/SIO) during transit along the Pacific Coast of Baja California 

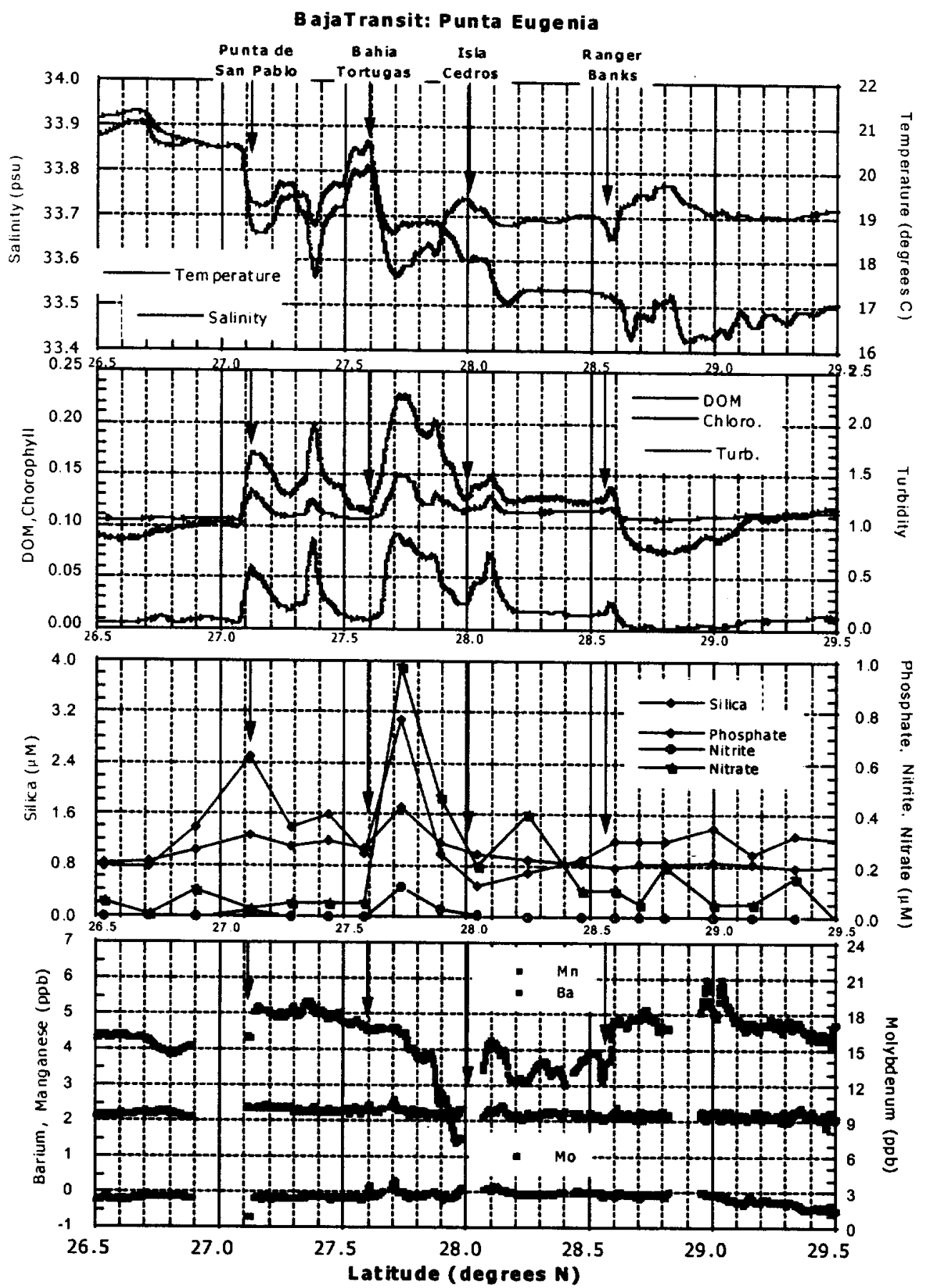

Figure 3. Detailed view of oceanographic and trace element data from the Baja transit off Punta Eugenia. 


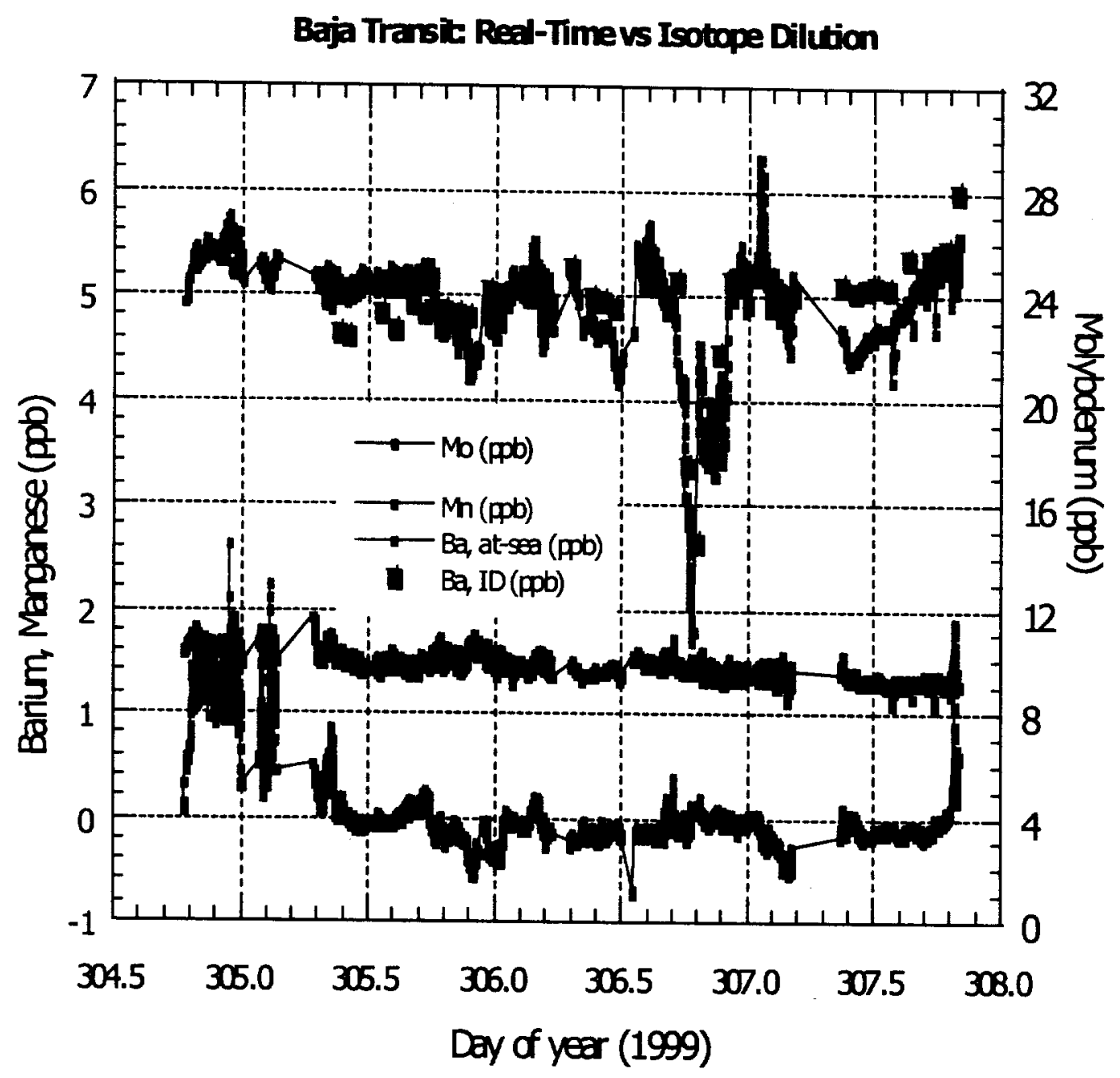

Figure 4. Trace element data for surface waters off Punta Eugenia showing pronounced Ba depletion. Ba abundances in red are real time, high resolution measurements taken during ship transit. Ba values shown by green squares are abundances in water samples collected on an hourly basis for validation, which were measured by isotope dilution ICPMS at LLNL. 

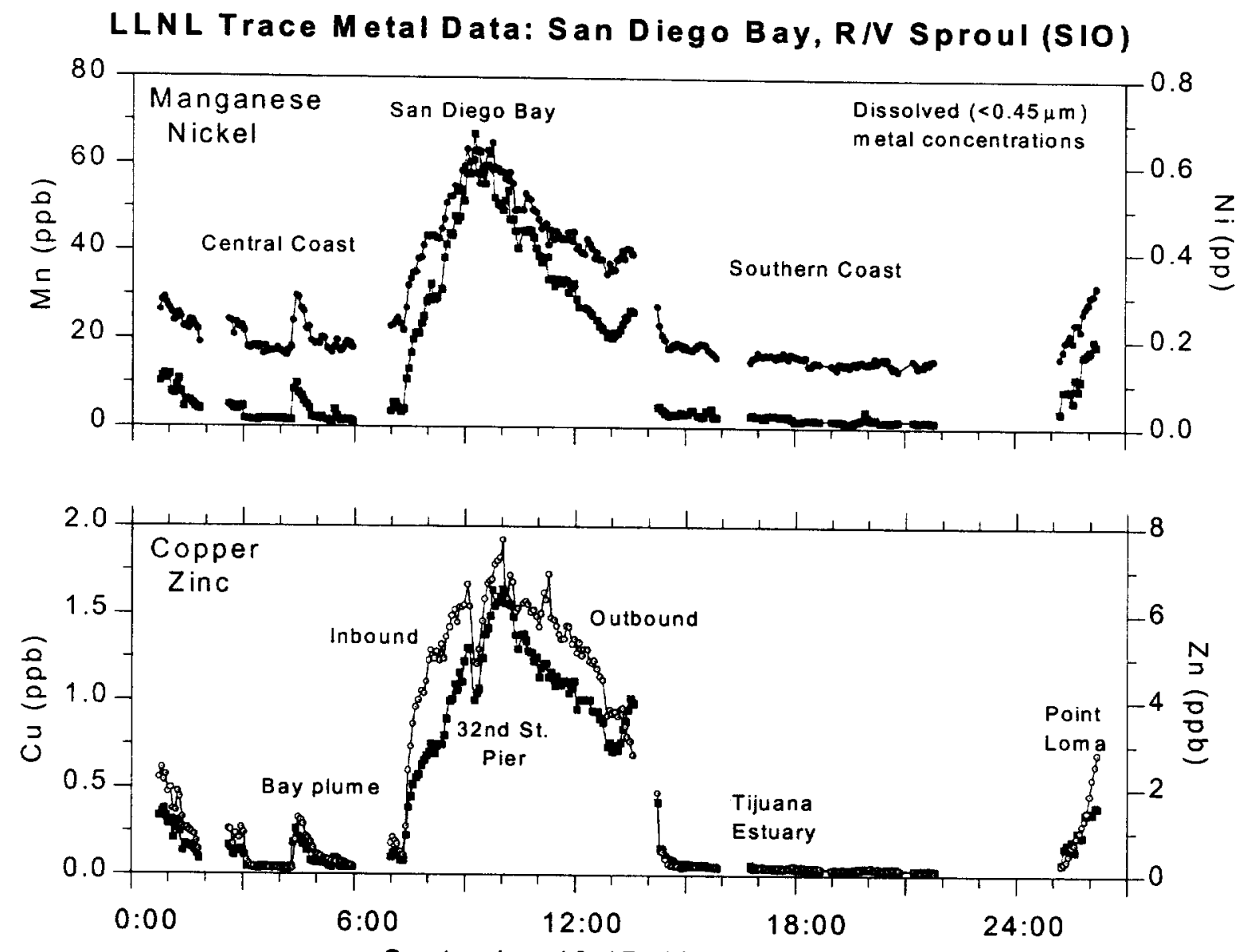

September 16-17, 1999 (GMT)

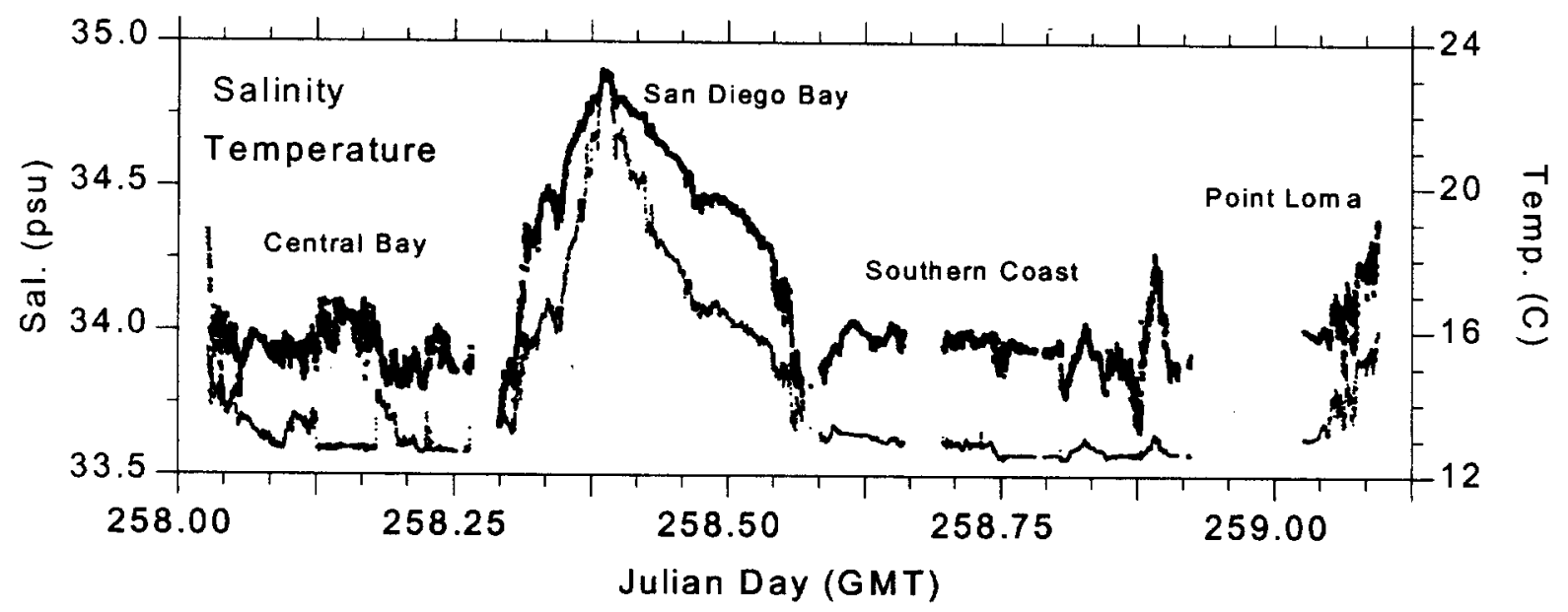

Figure 5. Data from the mid-September 1999 LLNL-sponsored cruise of the RV Sproul in San Diego Bay and the adjacent coastal ocean. The sensor data (temperature and salinity) have been averaged over ten seconds. The trace metal data have been time-corrected for transport between the towed body and ISIS unit, and for chemical processing. The trace metal data in these plots are Sc-normalized using at-sea calibration curves. All times are in GMT Julian Days. 
LLNL Plume Data: San Diego Bay mouth, R/V Sproul (S10)
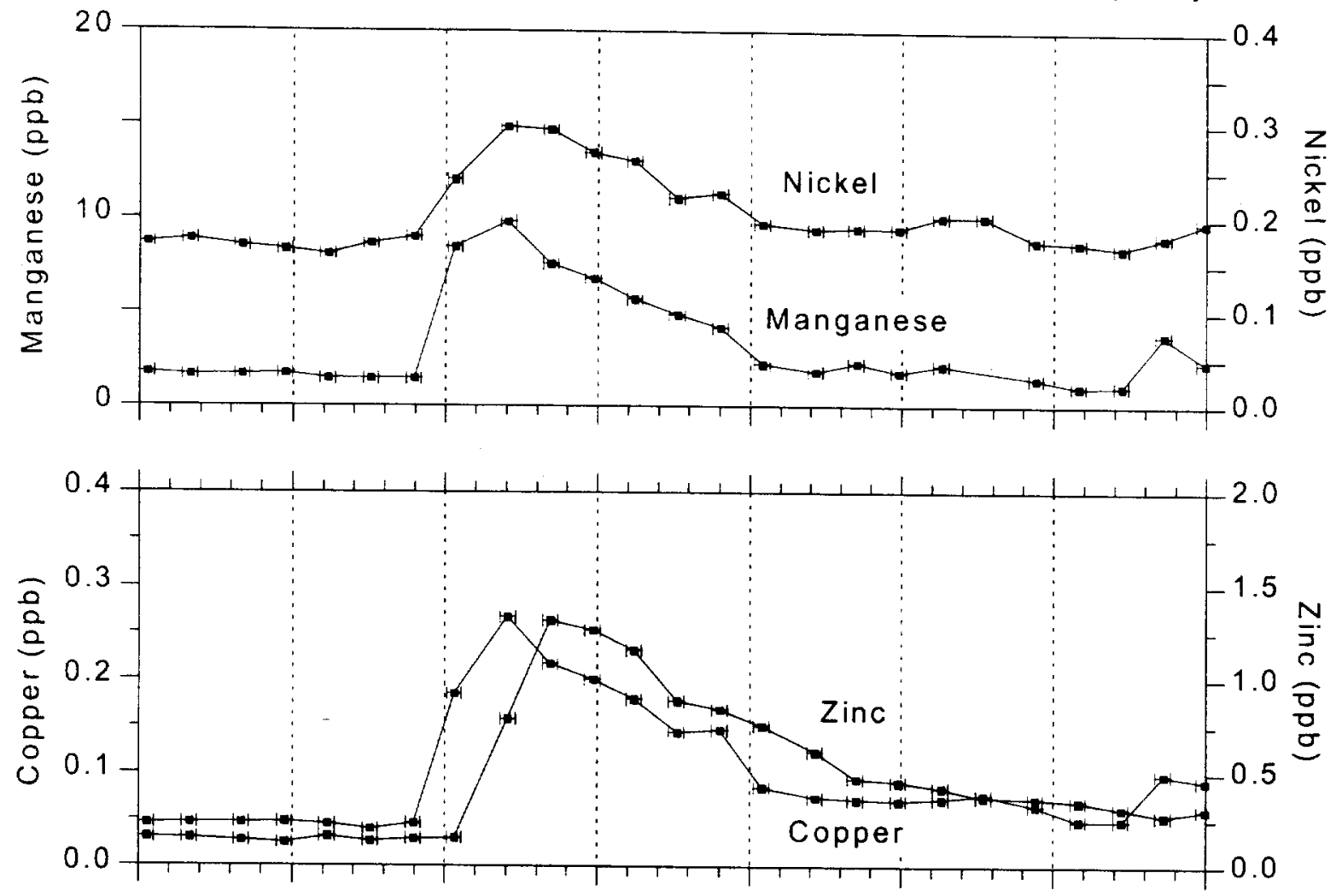

September 17, 1999 (GMT, corrected for time-lag)

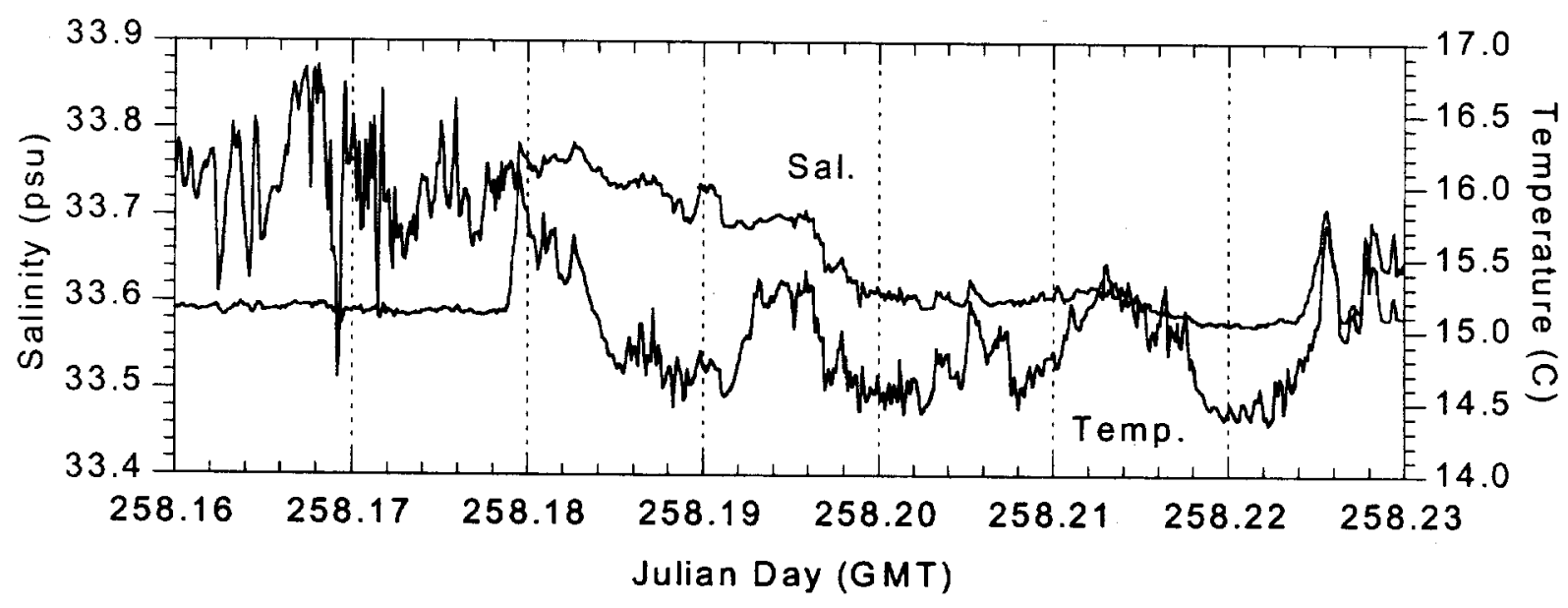

Figure 6. Transect of San Diego Bay plume in coastal ocean adjacent to the mouth of San Diego Bay. The plume is clearly characterized by trace metal enrichments in both highcontrast metals such as zinc, and low-contrast metals such as nickel. At a speed of 6 knots, the grid lines above (every 0.01 unit day) correspond to $2.66 \mathrm{~km}$, and a trace metal analysis cycle of 4 minutes allows a resolution of $0.75 \mathrm{~km}$. 


\section{References}

Bloxham M. J., Hill S. J., and Worsfold P. J. (1994) Determination of trace metals in sea-water and the on-line removal of matrix interferences by flow injection with inductively coupled plasma mass spectrometric detection. J. Anal. At. Spectrom. 9(9), 935-938.

Butler A. (1998) Acquisition and utilization of transition metal ions by marine organisms. Science 281(5374), 207-210.

DeCarlo E. H. and Resing J. A. (1998) Determination of picomolar concentrations of trace elements in high salinity fluids by FIA-ICP-MS (abstr.). Winter Conference on Plasma Spectrochemistry, 82-83.

DiBacco, C. (submitted) The influence of bay versus coastal waters on development and survival of shore crab larvae (Pachygrapsus crassipes) in southern California.

DiBacco, C. and LA. Levin. (in prep) Bay-ocean exchange of larvae revealed by pollutionbased trace elemental tags.

Ebdon L., Fisher A., Handley H., and Jones P. (1993) Determination of trace metals in concentrated brines using inductively coupled plasma mass spectrometry on-line preconcentration and matrix elimination with flow injection. J. Anal. At. Spectrom. 8(7), 979981.

Esser B. K. and Volpe A. M. (1998) Validation of the at-sea Inductively Coupled Plasma Mass Spectrometer (ICPMS). Lawrence Livermore National Laboratory, UCRL-ID-131940.

Falkner K. K., Klinkhammer G. P., Bowers T. S., Todd J. F., Lewis B. L., Landing W. M., and Edmond J. M. (1993) The behavior of barium in anoxic marine waters. Geochimica et Cosmochimica Acta 57, 537-554.

Falkowski P. G., Barber R. T., and Smetacek V. (1998) Biogeochemical controls and feedbacks on ocean primary production. Science 281(5374), 200-206.

Gaines, S.D., Bertness, M.D. Dispersal of juveniles and variable recruitment in sessile marine species. Nature 360: 579-580).

Jickells T. D. (1998) Nutrient biogeochemistry of the coastal zone. Science 281(5374), 217-222.

Kahru M., and Mitchell B. G. (1998) Spectral reflectance and adsorption of a massive red tide off Southern California. J. Geophys. Res., 103: 21,601-21,609.

Klinkhammer G. P. and Bender M. L. (1980) The distribution of manganese in the Pacific Ocean. Earth and Planetary Science Letters 46, 361-384.

Landing W. M. and Bruland K. W. (1980) Manganese in the North Pacific. Earth and Planetary Science Letters 49, 45-56.

Levin, L. A. (1990). A review of methods for labeling and tracking marine invertebrate larvae. Ophelia 32: 115-144. 
Lynn R. J. and Simpson J. J. (1987) The California Current system: The seasonal variability of its physical characteristics. Journal of Geophysical Research 92(C12), 12,947-12,966.

McGowan J. A., Cayan D. R., and Dorman L. M. (1998) Climate-ocean variability and ecosystem response in the Northeast Pacific. Science 281(5374), 210-217.

Mitchell, B. G. and Kahru M. (1998) Algorithms for SeaWiFS standard products developed with the CalCOFI bio-optical data set. Cal. Coop. Ocean Fish. Invest. R., 39:133-147.

Nozaki Y. (1997) A fresh look at element distribution in the North Pacific Ocean. Eos, Transactions, American Geophysical Union 78(21), 221-227.

NRC. (1998) Opportunities in Ocean Sciences: Challenges on the horizon. Ocean Studies Board, National Research Council,

O'Reilly J.E., et. al., (1998) Ocean color chlorophyll algorithms for SeaWiFS. J. Geophys. Res., 103:24,937-24,953.

Roughgarden J, S. Gaines and H. Possingham. (1988) Recruitment dynamics in complex life cycles. Science 241: 1460-1466.

Segovia-Zavala J. A., Delgadillo-Hinojosa F., and Alvarez-Borrego S. (1998) Cadmium in the coastal upwelling area adjacent to the California-Mexico border. Estuarine Coastal and Shelf Science 46(4), 475-481.

Sosik H.M. and Mitchell B. G. (1995) Light absorption by phytotplankton, photosynthetic pigments, and detritus in the California Current system. Deep Sea Res., 42(10):1717-1748.

Uppenbrink J., Hanson B., and Stone R. (1998) Chemistry and biology of the oceans. Science 281(5374), 189-189.

Willie S. N., lida Y., and McLaren J. W. (1998) Determination of $\mathrm{Cu}, \mathrm{Ni}, \mathrm{Zn}, \mathrm{Mn}, \mathrm{Co}, \mathrm{Pb}, \mathrm{Cd}$, and $V$ in seawater using flow injection ICP-MS. Atomic Spectroscopy 19(3), 67-72. 


\section{APPENDIX: LDRD 99-ERD-064 Augmentation Task, Don Eliason and Tom Sullivan, EESD}

\section{Assessment of Rapid Modeling / Measurement Capability for Hazardous Releases in Coastal Ocean Regions}

The purpose of this task was to survey the hydrodynamic/hydrologic modeling community to determine the state and availability of estuarine, coastal and ocean models for potential selection as building blocks in a coupled modeling and measurement real-time assessment system. Real-time assessment is a primary requirement for dealing with hazardous material releases into waterway systems, such as, rivers, bays, estuaries, coastal tidal zones and even the deep ocean. The object is to scientifically quantify impacts or determine specific chemical compositions in a transient environment. Models are an essential and necessary complement to measurement systems in order to both optimize the search for event specific tracers and/or deconvolve the initial source release characteristics of species, location, time of release and quantity. On the other hand, measurement systems data are essential and necessary complements to modeling systems to define the model skill and accuracy.

Our initial survey of available models indicates there are a wide range of working models at government laboratories including the US Army Corps of Engineering Waterways Engineering Station (WES), US Navy Oceanographic Center at Stennis and the NOAA Oceanographic and Services Division. There are also several academic university centers of excellence and private companies, which can provide excellent modeling codes. We have also joined the Marine Environmental Modeling information group, which is an international collegial source of models, modeling information and data references. These model sources could provide the base for beginning an LLNL coastal, estuarine and ocean dispersion assessment center. NOAA is a primary source of ocean databases that will be required for setup and initialization of modeling systems. US Navy databases might be an alternate (and possibly better) source for modeling support and initialization. 
Depending on the nature of the substance to be modeled and the nature of release (e.g. surface or at depth), 2D or 3D models may be required. If we model strictly buoyant releases such as oil or, small/minute floating debris, then 2D models, primarily driven by the near-surface winds should prove very adequate. Applied Sciences Associates of Rhode Island has a commercial package, which is suitable for this type work. In fact, it has become the standard oil spill assessment model for the US Coast Guard and the oil industry. However, for most elemental or chemical/biological transforming substances a full 3D/4D transport, transformation and diffusion modeling system will be required. WES has several model suites, which would be good starting points for this more advanced modeling. Their water quality model, for example, can address nutrients, tracers, eutrophication, seagrass, and other various trophic states and their interaction with nutrients; and a toxic substance model addresses transport and fate.

In assessing various models for consideration as candidates for incorporation in an LLNL capability, it quickly became apparent that most models fall into one of two classes. For one class, source codes were available, but technical support and efficient user interfaces were missing. These were primarily from academic and government facilities. The other class is commercial, and provides executable only codes with efficient, even slick, user inferface and graphic packages plus technical support and training. There are positive and negative aspects to each of these classes. The latter are definitely quick starts and produce professional output, albeit for a limited set of commercially viable problems. The former class takes longer to implement and adapt. However, one has the source code and the ability to adapt the models to any class of problem or substance as well as interface to a host of potential data sources.

A river, estuary, bay and coastal ocean hazardous substance modeling capability at LLNL would be closely aligned with the National Atmospheric Release Advisory (NARAC), in order to exploit the significant atmospheric real-time global databases and resident high resolution atmospheric forecast models. Within 2-3 years NARAC will be running the fully coupled Navy ocean-atmosphere model COAMPS which is a state-ofthe-art mesoscale ocean-atmosphere model. As the primary driver of surface and near 
surface transport and dispersion, high resolution surface wind forecasts will be a prime driver of many real-time assessments.

During this short study period contacts were made with DOE NN organization elements to determine if there would be interest supporting the development of the above described water modeling capabilities, either for real-time, emergency response assessment (i.e., a marine equivalent to NARAC), or solely as an assessment capability without the real-time response element. The initial inquiries suggest that the International Affairs elements of NN-50 and 60 have recent interest, but no budget submitted. The ongoing major reorganization of the emergency management component of DP-23 and NN-60 into the SO-40 structure, and the soon to follow NNSA structure have produced so much flux that none of our contacts is in a position to discuss a proposal at this time. 